\begin{tabular}{|c|c|c|c|c|}
\hline & \multicolumn{2}{|c|}{ Earty Therapy } & \multicolumn{2}{|c|}{ Adjunct Therapy } \\
\hline & $\begin{array}{c}\text { REQUIPP } \\
N=157 \\
\% \text { occurrence }\end{array}$ & $\begin{array}{c}\text { Placebo } \\
N=147 \\
N=0 \text { ocurrence }\end{array}$ & $\begin{array}{c}\text { REQUUP } \\
N=208 \\
\text { \% occurrence }\end{array}$ & 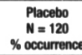 \\
\hline \multicolumn{5}{|l|}{ Heart Rate and Rhythm } \\
\hline Tachycardia & 1.9 & 0.0 & 1.0 & 0.0 \\
\hline Fibrillation Atrial & 1.9 & 0.0 & - & - \\
\hline Tachycardia Supraventricular & 1.3 & 0.0 & - & - \\
\hline Bradycardia & - & - & 1.0 & 0.0 \\
\hline \multicolumn{5}{|l|}{ Liver and Biliary System } \\
\hline Gamma - GT Increased & 1.3 & 0.7 & 1.0 & 0.0 \\
\hline Hepatic Enzymes Increased & 1.3 & 0.0 & - & - \\
\hline \multicolumn{5}{|l|}{ Metabolic and Nutritional } \\
\hline Alkaline Phosphate Increased & 2.5 & 1.4 & 1.0 & 0.0 \\
\hline Weight Decrease & - & - & 2.4 & 0.8 \\
\hline Hypoglycemia & 1.3 & 0.0 & - & - \\
\hline \multicolumn{5}{|l|}{ Musculoskeletal System } \\
\hline Arthralgia & - & - & 6.7 & 5.0 \\
\hline Arthritis & - & - & 2.9 & 0.8 \\
\hline Arthritis Aggravated & 1.3 & 0.0 & 1.4 & 0.0 \\
\hline \multicolumn{5}{|c|}{ Myocardial, Endocardial, Pericardial Valve } \\
\hline Myocardial Ischemia & 1.3 & 0.7 & - & - \\
\hline \multicolumn{5}{|l|}{ Psychiatric } \\
\hline Somnolence & 40.1 & 6.1 & 20.2 & 8.3 \\
\hline Anxiety & - & - & 6.3 & 3.3 \\
\hline Confusion & 5.1 & 1.4 & 8.7 & 1.7 \\
\hline Hallucination & 5.1 & 1.4 & 10.1 & 4.2 \\
\hline Nervousness & - & - & 4.8 & 2.5 \\
\hline Yawning & 3.2 & 0.0 & - & - \\
\hline Amnesia & 2.5 & 1.4 & 4.8 & 0.8 \\
\hline Dreaming Abnormal & - & - & 2.9 & 1.7 \\
\hline Depersonalization & - & - & 1.4 & 0.0 \\
\hline Paranoid Reaction & - & - & 1.4 & 0.0 \\
\hline Agitation & 1.3 & 0.7 & 1.0 & 0.0 \\
\hline Concentration Impaired & 1.9 & 0.0 & 1.0 & 0.0 \\
\hline Illusion & 1.3 & 0.0 & - & - \\
\hline Thinking Abnormal & - & - & 1.4 & 0.8 \\
\hline Apathy & - & - & 1.0 & 0.0 \\
\hline Increased Libido & - & - & 1.0 & 0.0 \\
\hline Personality Disorder & - & - & 1.0 & 0.0 \\
\hline \multicolumn{5}{|l|}{ Red Blood Cell } \\
\hline Anemia & - & - & 2.4 & 0.0 \\
\hline $\begin{array}{l}\text { Reproductive Male } \\
\text { Impotence }\end{array}$ & 2.5 & 1.4 & - & - \\
\hline Prostatic Disorder & - & - & 1.0 & 0.0 \\
\hline Penis Disorder & - & - & 1.3 & 0.0 \\
\hline Resistance Mechanism & & & & \\
\hline Upper Respiratory Tract Infection & ion - & - & 8.7 & 8.3 \\
\hline Infection Viral & 10.8 & 3.4 & 7.2 & 6.7 \\
\hline Respiratory System & & & & \\
\hline Pharyngitis & 6.4 & 4.1 & - & - \\
\hline $\begin{array}{l}\text { Rhinitis } \\
\text { Res }\end{array}$ & $\begin{array}{l}0.4 \\
3.8\end{array}$ & 2.7 & - & - \\
\hline Sinusitis & 3.8 & 2.7 & - & - \\
\hline Dyspnea & 3.2 & 0.0 & 2.9 & 1.7 \\
\hline Bronchitis & 2.5 & 1.4 & - & - \\
\hline Respiratory Disorder & 1.9 & 1.4 & 1.9 & 0.0 \\
\hline Pneumonia & 1.3 & 0.7 & 10 & 0.8 \\
\hline Coughing & _- & - & 1.4 & 0.8 \\
\hline Skin/Appendages & & & & \\
\hline Pruritis & - & - & 1.0 & 0.0 \\
\hline Urinary System & & & & \\
\hline Urinary Tract Infection & 5.1 & 4.1 & 6.3 & 2.5 \\
\hline Cystitis & 1.3 & 0.7 & - & - \\
\hline Micturition Frequency & - & - & 1.4 & 0.0 \\
\hline $\begin{array}{l}\text { Pyuria } \\
\text { Pand }\end{array}$ & - & - & 1.9 & 0.8 \\
\hline Urinary Incontinence & - & - & 1.9 & 0.8 \\
\hline Urinary Retention & 1.3 & 0.7 & - & - \\
\hline Dysuria & - & - & 1.0 & 0.0 \\
\hline Vascular Extracardiac & & & & \\
\hline Peripheral Ischemia & 2.5 & 0.0 & - & - \\
\hline Vision & & & & \\
\hline Vision Abnormal & 5.7 & 3.4 & - & - \\
\hline Eye Abnormality & 3.2 & 1.4 & - & - \\
\hline Diplopia & - & - & 1.9 & 0.8 \\
\hline Xerophthalmia & 1.9 & 0.0 & 1.4 & 0.8 \\
\hline Cataract & - & - & 1.4 & 0.8 \\
\hline Lacrimation Abnormal & - & - & 1.4 & 0.0 \\
\hline White Cell and Reticuloen & lothelial Sy & & & \\
\hline Eosinophilia & - & - & 1.4 & 0.0 \\
\hline
\end{tabular}

discontinued gradually over a 7-day period. The frequency of administration should be reduced from three times daily to twice daily for 4 days. For the remaining 3 days, the frequency should be reduced to once daily prior to complete withdrawal of REQUIP. Renal and Hepatic Impairment: In patients with mild to moderate renal impairment, REQUIPo may be titrated in the recommended manner according to clinical response. Patients with severe renal impairment or on hemodialysis have not been studied and administration of REQUIPe to such patients is not recommended. Patients with hepatic impairment have not been studied and administration of REQUIPo to such patients is not recommended. Estrogen Replacement Therapy: In patients already receiving estrogen replacement therapy, REQUIPo may be titrated in the recommended manner according to clinical response. However, if estrogen replacement therapy is stopped or started during treatment with REQUIPs, adjustment of the REQUIPe dosage may be required AVAILABILITY OF DOSAGE FORM: REQUIP is supplied as a pentagonal film-coated Tiltab tablet with beveled edges containing ropinirole (as ropinirole hydrochloride) as follows: $0.25 \mathrm{mg}$ - white imprinted with $\mathrm{SB}$ and 4890; $1.0 \mathrm{mg}$ - green imprinted with SB and 4892; $2.0 \mathrm{mg}$ - pale pink imprinted with $S B$ and $4893 ; 5.0 \mathrm{mg}$ - blue tablets imprinted with $S B$ and 4894. REQUIPO is available in bottles in the pack size of 100 tablets Full Product Monograph available to practitioners upon request.

GlaxoSmithKline Inc

7333 Mississauga Road North

Mississauga, Ontario

L5N $6\llcorner 4$

REQUIP is a registered trademark, used under license by GlaxoSmithKline Inc Date of preparation: June 18,2001

Date of revisions: March 31, 2004

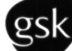

GlaxoSmithKline

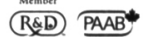

a: Incidence of adverse event $<1 \%$. Post-Marketing Experience - Patients treated with REQUIPo have rarely
reported suddenly falling asleep while engaged in activities of daily living including operation of motor vehicles which has sometimes resulted in accidents (see WARNINGS).

DOSAGE AND ADMINISTRATION: REQUIPe (ropinirole hydrochloride) should be taken three times daily. While administration of REQUIP with meals may improve gastrointestinal tolerance, REQUIPo may be taken with or without food. The recommended starting dosage is $0.25 \mathrm{mg}$ three times daily. Based on individual patient response, dosage should then be titrated by weekly increments of $0.25 \mathrm{mg}$ per dose as described in the table below. After week 4 , daily dosage may be increased by 0.5 to $1.0 \mathrm{mg}$ per dose on a weekly basis until an optimal therapeutic response is established. Smaller dose increments are recommended for patients who may be at risk for orthostatic symptoms.

\begin{tabular}{|lcccc|}
\hline & \multicolumn{4}{c|}{ Week } \\
\hline & 1 & 2 & 3 & 4 \\
\hline Unit Dose $(\mathrm{mg})$ & 0.25 & 0.5 & 0.75 & 1.0 \\
\hline Total Daily Dose $(\mathrm{mg})$ & 0.75 & 1.5 & 2.25 & 3.0 \\
\hline
\end{tabular}

In clinical trials, initial benefits were observed with $3 \mathrm{mg} /$ day and higher doses. Doses greater than $24 \mathrm{mg} /$ day have not been included in clinical trials. In a 5 year, double-blind study of early therapy in Parkinson's disease patients, the average daily dose of REQUIP' (based on the observed data set) was $10.1 \mathrm{mg}$ at 6 months (median dose $=9.0 \mathrm{mg}$ ), $14.4 \mathrm{mg}$ at 3 years (median dose $=15.0$ $\mathrm{mg}$ ), and $16.6 \mathrm{mg}$ at 5 years (median dose $=18.0 \mathrm{mg}$ ), regardless of levodopa supplementation. When REQUIP» is administered as adjunct therapy to levodopa, the dose of levodopa may be decreased gradually as tolerated once a therapeutic effect with REQUIP' has been observed. REQUIP` should be

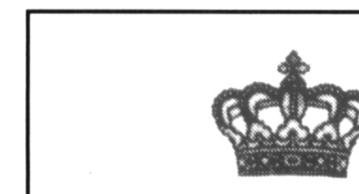

\section{KING MEDICAL}

\section{THE CANADIAN ELECTRODE PLACE}

- AMBU Blue Sensor • Neuroline

- CHALGREN Needles •Bar/Ring/Clip

- KENDALL Adhesive $\cdot$ NuTab

- KING MEDICAL Cables \& Adapters

- MAVIDON Lemon Skin Prep

- MEDTRONIC Mono/Conc. Needles

- PARKER LAB. Electrode Paste

- RADIANT Infrared Skin Thermometer

- 3M CANADA Micropore - Transpore

- D.O. WEAVER Ten20 • NuPrep

Bo-ject ${ }^{\mathrm{TM}}$ - Chalgren - Inoject ${ }^{\mathrm{TM}}$

Large stock of Hypodermic Needles

Tel 905-833-3545

Fax 905-833-3543

E-mail: soren@kingmedical.com Web Site: www.kingmedical.com

King Medical Ltd.

145 Kingsworth Road

King City • Ontario L7B 1K1

\section{ADVERTISERS INDEX}

Biogen Idec Inc.

Avonex - A-8, A-9, A-37, A-4

GlaxoSmithkline

Imitrex - IBC, A-20, A-21

Requip - A-3, A-38, A-39

Janssen-Ortho

Reminyl - OBC, A-34, A-35, A-36,

Kyphon - A-14

Lundbeck

Ebixa - A-6, A-7, A-30, A-31, A-32

Keppra - A-12, A-13, A-22, A-23

Pfizer

Lipitor - A-11, A-28, A-29

Sanofi-Aventis

Altace - A-15, A-33

Serono

Rebif - IFC, A-18, A-19

Teva Neuroscience

Copaxone - A-5, A-24, A-25

A-16, A-26, A-27, A-40

Classified Ads - A-40, A-41, A-42 